\title{
Akulturasi Budaya Pada Perkawinan Etnis Mandailing dan Minangkabau Di Nagari Sontang
}

\author{
Lisa Suhaimar, Susi Fitria Dewi \\ Program Studi Pendidikan Pancasila dan Kewarganegaraan \\ Universitas Negeri Padang \\ E-mail: lisasuhaimar@gmail.com
}

\begin{abstract}
ABSTRAK
Penelitian ini bertujuan untuk mendapatkan informasi mengenai proses akulturasi budaya pada perkawinan Etnis Mandailing dan Minangkabau di Nagari Sontang Cubadak. Penelitian menggunakan metode kualitatif. Data dikumpulkan melalui hasil wawancara dengan tokoh adat dan tokoh masyarakat, observasi dan melalui dokumentasi. Hasil penelitian ini menunjukkan bahwa adanya interaksi yang terjadi antara masyarakat Mandailing dan Minangkabau mengakibatkan terjadinya akulturasi. Akulturasi budaya yang terjadi antara kedua etnis ini dapat dilihat dari proses perkawinan masyarakat Mandailing yang sudah mengadopsi beberapa budaya Minangkabau. Akulturasi budaya yang terjadi di daerah ini diakibatkan adanya perkawinan antar etnis, migrasi dan interaksi antar etnis.
\end{abstract}

Kata Kunci: Akulturasi Budaya, Perkawinan Antar Etnis, Mandailing, Minangkabau

\section{ABSTRACT}

This study aims to obtain information about the process of cultural acculturation in Mandailing and Minangkabau Ethnic marriages in Nagari Sontang Cubadak. Research uses qualitative methods. data was collected through interviews with traditional leaders and community leaders, observation and through documentation. The results of this study indicate that the interaction between the Mandailing and Minangkabau communities resulted in acculturation. cultural acculturation that occurs between the two ethnic groups can be seen from the marriage process of the Mandailing people who have adopted the Minangkabau culture. Cultural acculturation that occurs in this area is due to inter-ethnic marriage, migration and inter-ethnic interaction.

Keywords : Cultural Acculturation, Ethnic Intermarriage, Mandailing, Minangkabau

(C) (D) (2) This work is licensed under the Creative Commons Attribution-ShareAlike 4.0 International License. @2019 This work is licensed under the Creative Com and Universitas Negeri Padang.
by author

\section{PENDAHULUAN}

Indonesia merupakan Negara yang terdiri dari berbagai suku dan etnik (multi etnik), terdapat sebanyak
1.340 yang tersebar dari Sabang sampai Merauke. Dengan adanya keberagaman etnik tidak menutup kemungkinan adanya interaksi sosial antar etnik, dari interaksi antar etnik 
akan menimbulkan proses sosial. Menurut Gilin-Gilin dalam (Soekanto, 2013) akibat yang ditimbulkan melalui interaksi sosial salah satunya ialah akulturasi.

Menurut Koentjaraningrat dalam Gusmanto (2016) akulturasi adalah perpaduan kebudayaan yang terjadi bila suatu kelompok manusia dengan kebudayaan tertentu dihadapkan dengan unsur-unsur budaya yang asing, sehingga unsur-unsur kebudayaan tersebut lambat laun diterima dan diolah dalam kebudayaan sendiri tanpa menghilangkan kepribadian budaya sendiri.

Akulturasi budaya dapat terjadi pada setiap lapisan masyarakat, termasuk pada masyarakat campuran. Akulturasi dapat terjadi karena adanya komunikasi antar budaya yang terjadi dalam masyarakat. Terutama pada masyarakat yang berbeda latar belakang budaya. Dalam penelitian ini, penulis akan meneliti bagaimana akulturasi yang terjadi pada perkawinan masyarakat Mandailing dan Minangkabau di nagari Sontang Cubadak Kabupaten Pasaman.

Nagari Sontang Cubadak merupakan salah satu daerah yang terdapat di Kabupaten Pasaman. Sebanyak 99\% masyarakat nagari Sontang Cubadak beragama Islam, sebagian besar penduduknya merupakan masyarakat Mandailing. Selain itu terdapat juga suku-suku lain seperti Suku Minangkabau, Suku Jawa dan Suku Batak. Banyaknya suku yang ada di daerah tersebut membuat daerah ini berpotensi mengalami akulturasi budaya.

Masyarakat Mandailing di nagari Sontang Cubadak saat ini lebih dominan menggunakan adat dan kebudayaan Minangkabau. Hal ini dapat dilihat dari prosesi perkawinan masyarakat Mandailing yang menggunakan prosesi perkawinan Minangkabau seperti: proses lamaran,duduk sarumah,batimbang tando ,manjapuik marapulai dan lainlain. Batimbang tando berarti bertukar tanda, dimana kedua belah pihak sudah terikat perjanjian yang tidak bisa dibatalkan. Sementara manjapuik muarapulai berarti dimana calon mempelai pria dijemput dan dibawa ke rumah calon mempelai wanita untuk melaksanakan akad nikah.

Akulturasi yang terjadi antara masyarakat Mandailing dan Minangkabau terjadi karena adanya perkawinan antar etnis di nagari Sontang cubadak. Proses ini sudah berlangsung lama yaitu sejak kerajaan Sontang Cubadak berdiri pada tahun 1570 M. Membutuhkan waktu yang lama bagi masyarakat untuk sampai pada tahap akulturasi, karena mereka harus melakukan penyesuaian dengan budaya baru, sehinga lambat laun tanpa disadari mereka telah menggabungkan budaya masingmasing. Akulturasi yang terlihat dari masyarakat Mandailing dan Minangkabau terlihat dari proses perkawinan dimana penggunaan adat Minangkabau tampak dalam beberapa acara seperti dalam penggunaan pakaian adat serta beberapa unsur Minangkabau dalam dekorasi saat pernikahan. Terkait akulturasi budaya pada perkawinan antar etnis di Indonesia, terdapat beberapa literatur yang dapat dijadikan sebagai literasi seperti pada penelitian yang dilakukan oleh Marestiana (2013) terdapat akulturasi budaya pada perkawinan anatar Etnis Sunda dan etnis Jawa. Akulturasi terjadi terlihat dari proses 
lamaran sampai pada tahap menetap setelah menikah. Penelitian lainnya yang dilakukan oleh Nurjannah (2016) menjelaskan bahwa perkawinan antar etnis yang dilakukan merupakan faktor migrasi, interaksi sosial dan perkawinan campuran. Penelitian yang relevan juga dilakukan Qaidar (2018) dalam perkawinan masyarakat di Desa Jeget Ayu Kabupaten Aceh Tengah terdapat akulturasi budaya pada perkawinan antara masyarakat Jawa dan Gayo, akulturasi terlihat dalam perkawinan yang memakai adat Jawa namun tetap dipandu menggunakan bahasa Gayo. Berdasarkan latar belakang masalah diatas maka penulis telah melakukan penelitian dengan judul "Akulturasi budaya pada Perkawinan Masyarakat Mandailing Dengan Masyarakat Minangkabau Di Nagari Sontang Cubadak".

\section{METODE PENELITIAN}

Jenis penelitian ini adalah penelitian deskriptif menggunakan pendekatan kualitatif. Moleong (2011) mengatakan bahwa metodelogi kualitatif merupakan penelitian data deskriftif berupa tertulis maupun lisan dari orang-orang yang diamati. Penelitian deskriftif ini bertujuan untuk memberikan gambaran mengenai suatu masyarakat atau sekelompok orang tertentu atau menggambarkan suatu gejala atau hubungan antara dua gejala atau lebih (Soehartono:2012). Lokasi penelitian merupakan objek penelitian dimana kegiatan penelitian akan dilakukan. Penentuan informasi penelitian ini adalah penelitian ditetapkan secara purposive sampling, penelitian dengan tujuan mengambil informan dari orang-orang yang benar-benar mengetahui dan dapat memberi informasi tentang permasalahan yang diteliti. Hal ini dilakukan untuk menetapkan orang-orang yang akan dijadikan sasaran penelitian. Purpose sampling adalah teknik yang dilakukan oleh peneliti dalam mempertimbangkan untuk mengambil sample. Teknik pengumpulan data dalam penelitian ini ialah melalui observasi, wawancara dan studi dokumentasi (Sugiyono, 2018). Teknik Analisa Keabsahan Data merupakan salah satu bagian yang sangat penting dalam penelitian kualitatif, untuk mengetahui derajat kepercayaan dari hasil penelitian yang dilakukan. Teknik yang digunakan penulis ialah teknik triangulasi Triangulasiadalah suatu pengecekan atau pemeriksaaan data melalui berbagai sumber, metode dan teknik pengumpulan data yang ada (Sugiyono, 2018).

\section{HASIL DAN PEMBAHASAN}

\section{Prosesi Perkawinan Masyarakat di Nagari Sontang Cubadak.}

Akulturasi terjadi setelah melewati proses yang panjang. Akulturasi budaya menunjuk pada perilaku individu atau kelompok individu yang berinteraksi dengan budaya tertentu. Dalam hal ini budaya Mandailing berinteraksi dengan budaya Minangkabau dan terjadinya perkawinan antara etnis Mandailing dan Minangkabau yang mejadi titik tolak terjadinya akulturasi sampai saat ini.

Akulturasi budaya yang terjadi antara etnis Mandailing dan Minangkabau dalam pelaksanaan upacara perkawinan masyarakat nagari Sontang Cubadak dapat dilihat dari proses pernikahan yang dikakukan baik sebelum pernikahan, maupun setelah pernikahan khusunya 
dalam melakukan resepsi, sehingg upacara perkawinan pada masyarakat Mandailing di nagari ini tidak lagi murni menggunakan adat Mandailing seperti yang terjadi di Sumatra Utara. Menurut bapak Nasrun Nasution salah satu tokoh adat Mandailing di nagari Sontang Cubadak saat wawancara banyak dari budaya Minangkabau yang di gunakan masyarakat Mandailing seperti dalam pewarisan, perkawinan, dan sistem kekerabatan.

Perkawinan merupakan cara untuk mementuk keluarga yang sah menurut hukum agama dan negara. Berdasarkan Undang-undang no 1 tahun 1974 perkawinan ialah ikatan lahir bathin antara seorang pria dengan seorang wanita sebagai suami istri dengan tujuan mementuk keluarga (rumah tangga) yang bahagia dan kekal berdasarkan Ketuhanan Yang Maha Esa. Perkawinan dilaksankan sesuai dengan adat masing-masing orang yang melakukannya. Perekawinan merupakan suatu jalan untuk membentuk keluarga yang sah dan salah satu hak asasi manusia yang diatur dalam UU No.39/1999 yaitu hak berkeluarga dan melanjutkan keturunan (Akmal, 2015). Di nagari Sontang Cubadak perkawinan dilakukan menggunakan adat Mandailing dan Minangkabau.

Akulturasi antar budaya Mandailing dan Minangkabau dalam pelaksanaan upacara perkawinan pada masyarakat Mandailing dapat dilihat dari prosesi lamaran, duduak sarumah, batimbang tando, malam bainai, akad nikah, basanding di Pelaminan, dan acara maradadat.

\section{a. Lamaran dan Batimbang Tando}

Lamaran atau istilah dalam bahasa Mandailing manyapai boru adalah prosesi keluarga dari calon mempelai laki-laki yaitu anggota keluarga yang di tuakan melakukan lamaran ke rumah calon mempelai perempuan dengan membawa sirih, pinang, rokok dan tembakau. Keluarga laki-laki yang datang disambut oleh keluarga perempuan.

Batimbang tando merupakan bentuk akulturasi budaya antara masyarakat Mandailing dan Minangkabau di nagari Sontang Cubadak, karena masyarakat Mandailing di Sumatra Utara tidak melakukan prosesi batimbang tando. Masyarakat Mandailing di nagari Sontang Cubadak melakukan prosesi ini sebelum melakukan perkawinan, hal ini merupakan hal yang penting bagi masyarakat Mandailing dalam acara ini pihak keluarga laki-laki datang kerumah calon mempelai perempuan dengan membawa barang yang akan saling ditukar. Barang yang akan ditukar seperti keris atau kain sarung dan baju.

Berikut gambar saat prosesi lamaran dan batimbang tando:

\section{Gambar 1. Lamaran dan Batimbang Tando}
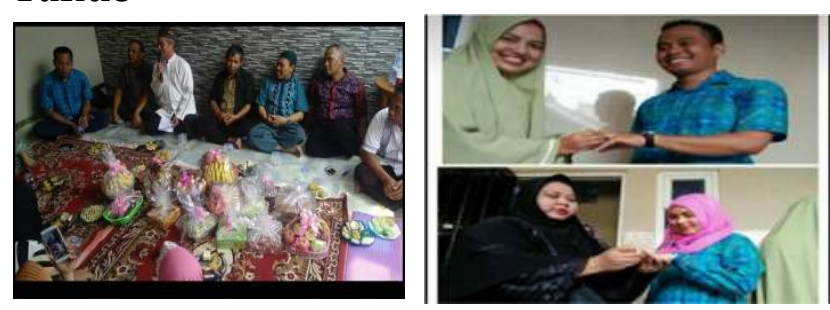

Sumber: Dokumentasi Pribadi

\section{b. Duduk Sarumah}

Duduak sarumah merupakan acara yang dilakukan untuk membahas perkawinan yang akan berlangsung dengan mengumpulkan 
keluarga, lalu setelah itu mengumpulkan orang yang dituakan seperti ninik mamak, hatobangon dan urang sakampung untuk memahas waktu pernikahan.

\section{c. Malam Bainai}

Malam berinai, merupakan salah satu bentuk akulturasi budaya yang terjadi antara masyarakat Mandailing dan Minangkabau. Berianai dilakukan pada malam hari sebelum pernikahan dilangsungkan. Pada malam ini calon mempelai perempuan akan di inai di kuku, telapak tangan dan jarinya, hal ini dilakukan bersama teman-temannya anak gadis dari keluarga atau temanteman dekatnya. Acara ini merupakan acara yang di adopsi dari budaya masyarakat Minangkabau, adat Melayu dan India. Jadi akulturasi tidak hanya dari unsur Minangkabau tapi juga unsur budaya lain. Berikut gambar dari acara bainai dalam acara adat di nagari Sontang Cubadak:

\section{Gambar 2 Bainai}
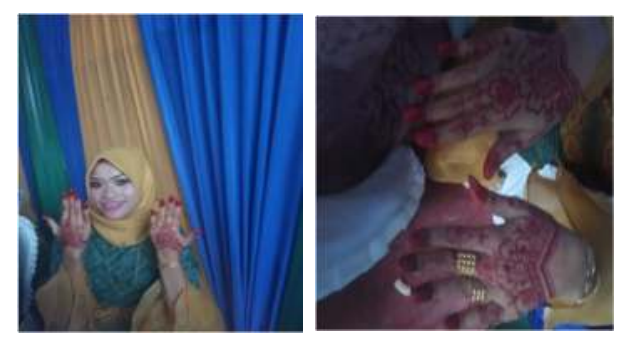

Sumber: dokumentasi pribadi

\section{d. Akad Nikah}

Proses paling penting dan merupakan acara inti dari semua proses yang dilakukan. Pada umumnya acara akad nikah di nagari Sontang Cubadak sama dengan akad nikah pada umumnya dilaksanakan di Rumah mempelai wanita atau dilaksanakan di Kantor Urusan Agama setempat. Sebelum acara ini dilakukan maka maraplai akan dijempt untuk dibawa ke tempat akad nikah dilakukan. Yang menjemputnya ialah pihak kelurga mempelai perempuan seperti bibi, kakak atau saudara yang lainnya. Berikut contoh acara akad nikah di nagari Sontang Cubadak.

\section{Gambar. 3 Akad}

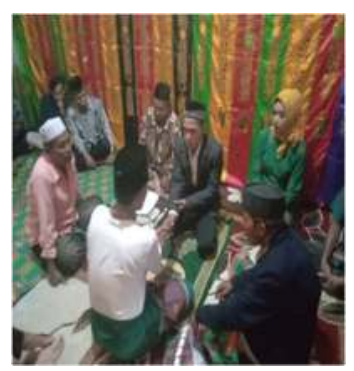

Sumber: Dokumentasi Pribadi

\section{e. Bersanding Di Pelaminan}

Prosesi bersanding di pelaminan dilakukan setelah acara akad nikah. Acara ini merupakan acara yang dilakukan oleh masyarakat Minangkabau. Masyarakat Mandailing di nagari Sontang Cubadak menggunakan dekorasi dan adat Minangkabau dalam acara resepsi pernikahan. Pakaian adat yang digunakan masyarakat Mandailing saat prosesi resepsi pernikahan ialah pakaian adat Minangkabau. Hal ini memang sudah lama terjadi akibat adanya perkawinan campuran. Dalam prosesi ini pengantin biasanya memakai tiga atau empat stel baju. Dua baju yang digunakan ialah baju khas Minangkabau seperti baju sunting warna merah dan baju Minangkabau motif dan warna lainnya. Selain itu ada juga beberapa pengantin Mandailing yang memakai baju khas Tapanuli Selatan. Dan baju lain ialah baju modern sesuai pilihan pengantin. Dekorasi dalam pernikahan ialah dekorasi modern dan memasukkan beberapa unsur Minangkabau. Berikut gambar dalam acara bersanding di pelaminan: 


\section{Gambar. 4 Bersanding di Pelaminan}
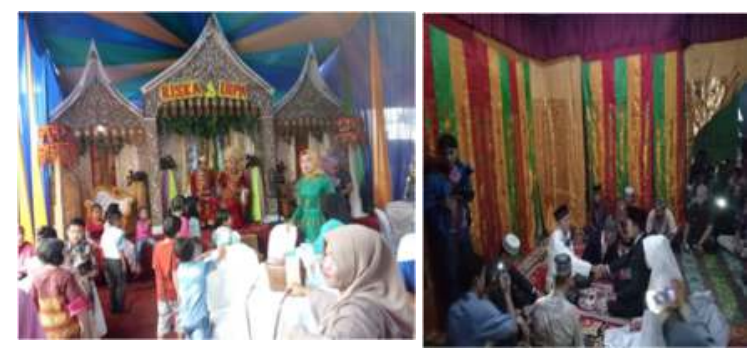

Sumber: Dokumentasi Priadi

\section{f. Maradat}

Maradat merupakan acara adat yang dilakukan masyarakat Mandailing setelah acara resepsi dilakukan. Pada acara maradat ini semua tokoh adat akan berkumpul dirumah pengantin untuk melakukan prosesi adat yang dipimpin oleh Ninik Mamak. Dalam acara ini kedua pengantin akan diberi nasehat untuk bekal dalam menjalankan kehidupan rumah tangganya kedepan. Acara ini dilangsungkan setelah Maghrib dan selesai sebelum sholat Isya dimulai. Berikut gambar acara maradat dalam masyarakat Mandailing di Nagari Sontang Cubadak:

\section{Gambar. 5 Maradat}

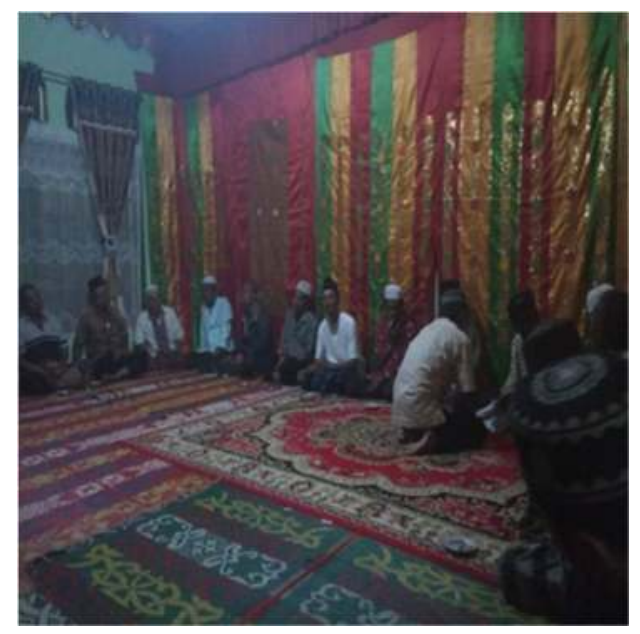

Perubahan-perubahan yang terjadi dalam perkawinan masyarakat Mandailing sejalan dengan eksistensi teori akulturasi. Akulturasi budaya
Volume 1 No. 22018

yang terlihat dari prosesi diatas dimana masyarakat Mandailing di nagari Sontang Cubadak mengadopsi beberapa budaya luar salah satunya ialah Minangkabau, namun dalam setiap prosesi yang digunakan bahasa yang digunakan ialah bahasa Mandailing.

\section{KESIMPULAN}

Berdasarkan hasil penelitian melalui analisis data secara deskriftif, maka dapat disimpulkan bahwa proses akulturasi budaya antara masyarakat Mandailing dan Minangkabau di nagari Sontang Cubadak terlihat dari proses perkawinan masyarakat Mandailing yang mengadopsi beberapa budaya adat Minangkabau.Akulturasi budaya disebabkan adanya interaksi antar budaya, migrasi dan perkawinan antar etnis di masa lalu.

Dalam prosesi perkawinan masyarakat Mandailing tidak memeliki konsistensi yang jelas dalam adat perkawinannya, namun terlihat cenderung menggunakan adat Minangkabau seperti tradisi batimbang tando,malam bainai, dan bersanding di pelaminan, namun dalam setiap prosesi bahasa Mandailing adalah bahasa yang digunakan dan beberapa unsur Mandailing masih digunakan.

\section{DAFTAR PUSTAKA}

Akmal. (2015). Hak Asasi Manusia (Teori dan Praktik). Padang: UNP Press.

Marestiana, A., Imron, A., \& Basri, M. (2013). Akulturasi Perkawinan Suku Sunda Dan Suku Jawa Di Desa Tanjung Ratu Kecamatan Katibung Kabupaten Lampung 
122 | Akulturasi Budaya..

Selatan. Pesagi (Jurnal Pendidikan dan Penelitian Sejarah), 1(1).

Moleong, J Lexy. (2011). Meteodologi Penelitian Kualitatif. Bandung: Remaja Rosdakarya

Nurjannah, N., \& Ayu, A. G. (2016). Akulturasi Budaya pada Upacara Perkawinan Masyarakat Jawa di Desa Perlis Kecamatan Brandan Barat. Anthropos: Jurnal Antropologi Sosial dan Budaya (Journal of Social and Cultural Anthropology), 2(2), 121-129.

Gusmanto, R. (2017). Akulturasi Minangkabau, Jawa, Dan Mandailing Dalam Kesenian Ronggiang Pasamandi Kabupaten Pasaman Barat Provinsi Sumatera Barat. Garak Jo Garik: Jurnal Pengkajian dan Penciptaan Seni, 12(2).

Soerjono, S. (2013). Sosiologi Suatu Pengantar. Jakarta: Rajawali Pres Soehartono, I. (2012). Metode Penelitian Sosial (suatu Teknik Penelitian Bidang Kesejahteraan Sosial dan Ilmu Sosial Lainnya). Bandung: PT. Remaja Rosdakarya.

Sugiyono. (2016). Metode Penelitian Kuantitatif Kualitatif dan $R \& D$, Bandung: Alfabeta Syafii,

Ritonga, A. S., \& Bahri, S. (2017). Asimilasi budaya melayu terhadap budaya pendatang di kecamatan senapelan kota pekanbaru. Jurnal Online Mahasiswa Fakultas Ilmu Sosial dan Ilmu Politik Universitas Riau, 4(2), 1-15.

Qaidar, A., Anisah, N., \& Si, M. (2018). Proses Akulturasi Budaya melalui Perkawinan Campuran Suku Jawa-Gayo di Desa Jeget Ayu Kecamatan Jagong Jeget Kabupaten Aceh Tengah. Jurnal
Ilmiah Mahasiswa Fakultas Ilmu Sosial E Ilmu Politik, 3(3). 